\title{
Becoming-Grizzly: Bodily Molecularity and the Animal that Becomes
}

\author{
Astrida NeIMANIS
}

The becoming-animal of the human is real, even if the animal the human becomes is not; and the becoming-other of the animal is real, even if that something other it becomes is not. (Deleuze and Guattari, A Thousand Plateaus 238)

I have to mutually mutate into a wild animal to handle the life I live out here. (Timothy Treadwell, in a letter to Marnie Gaede)

In Werner Herzog's documentary film Grizzly Man, we are acquainted with Timothy Treadwell and the "becoming-animal" that lures him to return to the Alaskan wilderness for thirteen summers to live with the grizzly bears and other animals of the Katmai nature reserve. "Becoming-animal" is a concept articulated by French critical theorists Deleuze and Guattari in their book A Thousand Plateaus. In Deleuze and Guattari's own words, this becoming is an "unnatural participation," a "mixing of molecules" and a "multiplicity" that transforms the animal no less than the human-although the human, they note, does not "really" become an animal. As Herzog's film makes clear, this becoming-animal is not a speculative fiction. Becoming-animal happens to us. We experience it; we live it. This film thus also invites us to carefully consider the relation between Deleuze and Guattari's concept of becoming-animal and phenomenological accounts of lived embodiment. Despite the divergences between Deleuze and Guattari's philosophical practice and the phenomenological tradition, how might we understand becoming-animal as a modality of our lived, embodied experience? 
This paper undertakes an exploration of these questions, beginning with an account of Deleuze and Guattari's concept of "becoming-animal" in the context of their broader philosophical project. Yet I suggest that the meaning and implications of becoming-animal are helpfully elucidated by considering the ways in which some aspects of Deleuze and Guattari's practice can be understood as a radical or rhizomatic phenomenology of our lived experience. As such, we can understand how their practice in some ways radically extends the work of French phenomenologist Merleau-Ponty, who articulates, and anticipates the further development of, a theory of lived embodiment that is not limited by notions of the human body as merely static and subjectified. What emerges between the two philosophies is the possibility of bodily molecularity as a mode of lived embodiment. I argue that this molecularity is what enables the potential interpermeation of bodies across and through their difference, such as occurs in the event of becoming-animal. Alphonso Lingis's descriptions of our becoming-animal as lived experience serve here as an evocative source for clarifying this proposition further.

But Deleuze and Guattari also note that becoming-animal is a risky experiment, and that its outcome cannot be guaranteed. This paper therefore ends by returning to Herzog's Grizzly Man to further consider what these risks and consequences of becoming-animal might be-not only for the human who becomes, but also for the animal that is pulled into this becoming alongside of her.

\section{What is Becoming-Animal?}

In explicating their concept "becoming-animal," Deleuze and Guattari are very clear about what such a becoming is not (Thousand 239). They move swiftly to reject any associations

with other theoretical frameworks that invoke the animal to explore human behaviour and 
psychology. Becoming-animal has nothing to do with Jung's animal archetypes, or Bachelard's symbolism, or any other such interpretations of the subconscious or dreams wherein one "becomes" an animal as a metaphor or symbol that in fact "means" something else, they assert. Similarly, becoming-animal is not a Levi-Straussian structural relationship that establishes symmetrical correspondences between sets of animals and humans. Deleuze and Guattari make it clear that because neither of these interpretations of becoming-animal appreciate the becominganimal as real, neither is satisfactory.

Yet at the same time, explain Deleuze and Guattari, a human does not "really" or literally become an animal such that no human would remain. Becoming produces nothing but itself, they argue. Nor, however, is becoming-animal a "real" becoming in an evolutionary or filial sense, whereby something "becomes" through a process of natural selection (such as when ape becomes hominid). Finally, they assert, becoming-animal is never simply an imitation of the animal by the human, nor even an identification with the animal, although both of these engagements, if necessary, can inform the process of becoming-animal. For example, if you "become dog" by barking, Deleuze and Guattari tell us, it is not the identitarian concept-the "signified" dog—-that you become. Rather, if barking is "done with enough feeling, with enough necessity and composition, you emit a molecular dog" (Thousand 275). The dog inside you wells up. Your barking brings your molecules into contact with the canine.

In fact, assert Deleuze and Guattari, becoming-animal, like all becomings, is "molecular" (Thousand 272-275). It is communicative and contagious, working according to a logic of infection, whereby human molecularity and animal molecularity collide in each others's zones of proximity. Like a cold virus, the particles of human and the particles of animal literally infect one another and mix together to form a new singularity, irreducible to either of the two parts. 
Because it is a mixing, it could never be a "representation" or an "imitation" of one part or the other. Moreover, this comingling or comixing underlines why the becoming itself is real. Even though humans do not "really" become animals, a block of becoming forms between the human and animal, where their molecularities mix-this is what is "real." In this sense, becominganimal is never a teleological process, where human has a goal to "be" ultimately animal. As a becoming between human and animal, becoming-animal is always a double movement (305). While it affects the animal as much as the human, the becoming itself is a third term that exerts this transformative force.

Becoming-animal is moreover part of a spectrum of becomings which all tend towards becoming-imperceptible (Thousand 279). This underlines a final key point that Deleuze and Guattari stress: Becoming (animal or other) is always a multiplicity. Becoming continually transforms itself along a string of other multiplicities, according to those thresholds or doors that the becoming encounters (249). Whatever the animal or human "becomes," this is not the accomplishment of the becoming as a final destination, but rather one of these doors or thresholds that can open to a further becoming.

But what is a "comingling of forces" or a "mixing of molecules"? What does it mean, for example, to "emit a molecular dog?" And why is this significant? What might becoming-animal teach us or reveal to us about animals and ourselves? Without a deeper understanding of Deleuze and Guattari's broader philosophical project to buttress this concept, becoming-animal sounds at best like speculative fiction. How do we, or can we, live this concept in our own flesh, blood and bones? 


\section{Becoming-Animal as Radical Phenomenological Description}

Becoming-animal is one figuration of difference within Deleuze and Guattari's philosophy that seeks to undermine the Western metaphysical notion of human subjectivity as the centre of the world. Deleuze and Guattari strive to reveal how all bodies-human bodies, other material bodies, concept-bodies, etc.- are in fact vectors and intersections of the myriad forces and energies that compose these bodies, and connect them to other bodies. Being is for them always becoming; every body is composed of speeds and slownesses, and is therefore defined by its thresholds of changeability rather than by a static essence, or some discretely bounded, impermeable ideal of interiority. For Deleuze and Guattari, relations, movements and pragmatics are the important moments for analysis. Becoming-animal, as a block of becoming between human and animal, is thus one way in which they illustrate the material challenge to our belief in the stable, hegemonic and subjectified human condition. Becoming-animal proposes that our discrete subjectivities are in fact delightfully porous. Our material interconnection with other bodies, such as animal bodies, consistently pulls us out of our place of human privilege. Furthermore, Deleuze and Guattari's insistence that becomings-animal involve nuptials that are "unnatural" and never "filiative" does not mean that the animal and the human are totally discrete and unconnected to one another. Rather, this is what our inherited ontological and metaphysical paradigms would have us believe. Such becomings are unnatural because they challenge our inherited "natural order of things," whereby man sits atop and apart from the menagerie of the material world. ${ }^{1}$

Against the (teleological, rooted) tree model of thought, Deleuze and Guattari wish to offer a rhizomatic model—one of connection, unanticipated direction, and multiplicity, with no privileged centre. However, they do not dispute the fact that the world also coagulates into orders 
and systems according to which beings and subjects are organized. For this reason, it is not a contradiction to speak of the "human" and the "animal" as in some sense distinct entities, between which becoming-animal emerges. Although both humans and animals are ultimately specific choreographies of energy and matter that intersect with and beyond one another upon a plane of consistency (the plane that accommodates all possibilities and potentials of the forces that circulate thereon), planes of organization are always interrupting the plane of consistency by extracting and stratifying forces into forms (Thousand 269-270, 506-507). Subjectivity and signification are two stratifying operations in which human bodies are inevitably caught up. Yet Deleuze and Guattari do wish to reveal to us the sense in which such forms are always fugacious, and stratifications are always ephemeral. Any "organized" subject or entity is only ever a pause or a resting place in the movements of forces that constantly cut through these orders, and can deliver to them, at times, a shattering blow. Becoming-animal, they suggest, can be one such assault.

Moreover, to ask whether their work in general, and becoming-animal in particular, is descriptive or prescriptive is a false choice, for it is both. Certainly, their work is peppered with direct calls to action—“Don't be one or multiple, be multiplicities!" (Thousand 24). "Don't bring out the General in you!" (25). "Lodge yourself on a stratum, experiment with the opportunities it offers" (161). Such solicitations point to the political impulse in their work that has been increasingly taken up in contemporary political theory and anti-oppression politics. ${ }^{2}$ Yet to view their work primarily as prescriptive misses the point already noted above: such prescriptions do not intend to do away with the various planes of organization that stratify and organize some status quo (such as "subjectivity"), but rather they express dismay at the invasive hegemony of such stratification. Even if one is a "multiplicity," one will still also always be "one," in a certain 
sense. The "prescriptions" they offer are in fact predominantly ways to corral our attention, shift our focus, and invite us to embrace an ontological mode of becoming in which we are already caught up, but which we fail to appreciate, or which we might even actively negate. With becoming-animal, the prescription at work is to attune ourselves to these becomings, and to understand what we might learn from them-about our own embodiment, about that of the others with whom we become, and about our dominant ontological paradigms and concepts of subjectivity. For this reason we cannot really appreciate the critical element of their philosophy without considering the ways in which it is significantly descriptive. What the work of Deleuze and Guattari gives us is studied attention to forces and matter in their real compositions, and to the way these compositions always interpermeate one another. By describing a radical ontological amendment to our thought, their work invites us to change the way we categorize the world, which in fact changes everything. Does not their description of becoming-animal invite you to deconstruct the thickwall built around your own human subjectivity?

In fact, precisely because becoming-animal is a thick description of life, I read this (and other figurations within Deleuze and Guattari's philosophical practice) as a radical or "rhizomatic" phenomenology. Despite their focused attention on the transformations of and relations between things that occur at the surface, part of what they offer us in the end are deep and complex descriptions of life-far deeper in fact than most traditional phenomenologies. This depth or thickness arises from Deleuze and Guattari's expanded understanding of the ontological status of the "things" they are describing. Undoubtedly, these ontological investments challenge traditional phenomenology in many important ways. If we are to suggest that Deleuze and Guattari "go back to the things themselves" according to the phenomenological tradition inaugurated by Edmund Husserl, they certainly do not encounter "things" in any traditional 
metaphysical sense. Instead, they encounter the coagulations and intersections of forces and materiality mentioned above. These compositions are not defined by any ideal essence, but rather by their speeds and slownesses, and the relationships into which they are capable of entering. "Things," or what is "real" for Deleuze and Guattari, are both actual and virtual (that is, both what is already assembled or stratified, as well as the cloud of indeterminate potentiality that hovers around this stratification). ${ }^{3}$ These "things" are produced via what Deleuze calls the "intensive"-morphogenetic processes that are as real as the things they (temporarily, ephemerally) produce. "What is," for a Deleuzian ontology, is inseparable from how it is, how it might have been and how it might be. And this is what Deleuze and Guattari describe in various parts of their philosophy. But because of such departures from the Western metaphysics they have inherited, in order to describe these "things" (which are in fact always becomings, or movements, or the facilitators of becomings and movements) Deleuze and Guattari must deploy concepts and vocabulary (i.e., the "actual," the "virtual," the "intensive" which territorialize and deterritorialize "planes of organization" and "planes of consistency") that a traditional phenomenological lexicon (i.e., "things" in the "world") cannot offer them.

"Becoming-animal," I propose, is one such radical phenomenological description. By thinking about becoming-animal in these terms, moreover, we can more clearly see how such a phenomenon might play out in relation to our own lived experience. In this concept, Deleuze and Guattari describe a phenomenon of becoming-intense. This is not a speculative fiction or a hypothesis of chemistry or physics, but a real event that morphogenetically alters the stratified beings on either side of the becoming. Gathering filmic, literary and other examples from our collective Western cultural consciousness, Deleuze and Guattari describe such becomingsanimal, including their actuality (for example, the Werewolf or the barking man who emits a 
molecular dog), their virtuality (the thresholds and doors that may potentially open onto becomings- $n$, or Virginia Woolf's "saturation of every atom" [Thousand 280]) and their intensive processes (the mixing, comingling, symbiotic infection) that are all necessary in order to understand the thickness of this phenomenon.

Still, one of Deleuze and Guattari's primary criticisms of phenomenology is its reliance on a knowing human subject whose descriptions could only ever reveal a circumscribed humancentred opinion —as they put it, an Urdoxa masquerading as truth (What is Philosophy? 149150). This criticism underlines another related divergence between phenomenology and rhizomatics: If the phenomenologist describes the world as she experiences it, the rhizomatic philosopher would question how such human-centred experience could ever reveal the thick ontology of "things" proposed by Deleuze and Guattari. The concern is that the subjective human vantage point projects its own limited temporalization and spatialization, so that any meaning it discerns is bound to this human scale. How could a subjective human perspective possibly describe, for example, the molecular emission of the becoming-dog, if the human does not really become a dog? How could the human escape from her circumscribed vantage point to gain access to the subterranean and intensive subterfuges that are part of the "things" that a Deleuzian ontology counts as real? Such doubts are what will likely fuel objections both to my suggestion that Deleuze and Guattari's project is (even radically) phenomenological, and also to my proposal that the meaning and import of becoming-animal can be opened up through an existential embodied phenomenological approach. While some classical versions of phenomenology might not adequately quash such doubts, the embodied phenomenology of Merleau-Ponty proposes a useful opening. 


\section{Molecularity as Lived Embodiment}

According to Merleau-Ponty, the (human) body is a unity, but significantly, this unity is always "implicit and vague" (Phenomenology 198). The body, as Merleau-Ponty teaches us, is not an unthinking material mass directed by an all-powerful mind, soul or other homunculus, but rather a loosely held-together material choreography of ways that we are in the world. Consciousness, according to Merleau-Ponty, emerges from our various bodily modalitiesperception, affectivity, motility, and viscerality, in addition to cognition (the rational, analytical,

categorizing, and sometimes linguistic body). ${ }^{5}$ Merleau-Ponty does not deny that our cognitive bodies help us understand the world, but rather challenges the hegemony of this mode of knowledge by illuminating the other modes of knowing, being and becoming in which our bodies engage. In Deleuze and Guattari's criticism of the human subject, their target is likely this cognitive mode of embodiment, as well as those aspects of other modalities that tend towards organization, sedimentation, rational repetition and non-creative habit. This is the human body that is wedded and committed to its own comfortable sense of human scale, and thus what has already been enacted or imagined. But this human body and human-scaled perspective, which Deleuze and Guattari criticize as phenomenology's limit, are not all that the human body can be, as Merleau-Ponty shows us. The human body lives according to a number of modalities that are well-equipped to protest those operations by which human embodiment sediments into a subjectified identity; non-cognitive bodily modalities are far more adept at locating various lines of flight or escape. Our bodies are always erupting and disrupting the discipline they are subjected to in unpredictable ways. These disruptions are located in the fugitive affects, the visceral responses, and the startling perceptions that our cognitive and sedimented selves are unable to control or order upon what Deleuze and Guattari would call the plane of organization. 
Merleau-Ponty's embodied phenomenology already goes quite far in upsetting the notion of a sedimented subject capable of producing only Urdoxa. ${ }^{6}$ However, by bringing his phenomenology into (perhaps unnatural?) nuptials with Deleuze and Guattari's rhizomatics, we can push this departure even further. In Deleuze and Guattari's concept of molecularity, we find the means to articulate a radicalized version of Merleau-Ponty's notion of "the lived." Molecularity becomes a very real mode of the lived embodiment that underpins various aspects of our non-cognitive ways of being bodies. Through Deleuze and Guattari, we can come to understand human embodiment as comprised of molecular interactions with the world that are enacted through the perceptual, motor, affective and visceral modalities of living that MerleauPonty has described for us.

We see this becoming-molecular in the various assemblages into which the molecular body enters. For example, while our viscerality is part of that "loosely unified" human body assemblage, it is also part of a food production-consumption-excrement-waste treatment assemblage that extends far beyond the stratified "human body." By paying attention to our molecularity we in fact see how our molecular bodies constantly extend and disrupt the discrete bounds of our stratified bodies in all sorts of ways: we enter visceral becomings in mouthbecoming-apple or lung-becoming-smog; we entertain affective becomings in a mood-becomingProzac and perceptual becomings in eye-becoming-light; we live out motor becomings such as foot-becoming-gas pedal. Our molecularlity is what allows stratified bodily assemblages to enter into new and surprising relationships, and to be transformed and reconfigured by these nuptials. This molecularity is what enables intensive morphogenetic processes that affect and transform our bodies; this molecularity is what provides a means of connection between and across bodies that are radically different. 
While the language here is Deleuzian, these are assemblages that Merleau-Ponty surely acknowledges, not only in his descriptions of how the body and the world co-create one another, but specifically in his posthumously published work, the Visible and the Invisible, where he moves to articulate an ontology of the flesh. According to this ontology, all bodies participate in an elemental being, and thus also in each other. The flesh in Merleau-Ponty's words is an "interconnective tissue" and a "mesh" or a "web" that inter-implicates all bodies. The flesh is a "possibility, a latency" (Visible 133) that holds the yet-to-come difference latent within itself (136). As Merleau-Ponty describes, in this latency "there is already a kind of presence of other people within me" ("Experience" 56). Yet this otherness is not subsumed or assimilated by me in the experience of reversibility. Any full coincidence is blocked by the necessary dehiscence or écart that is part of the paradox of the flesh as an incorporated disincorporation. Like Deleuze and Guattari's in-between of multiplicitous becomings, Merleau-Ponty's flesh, as the zone of becomings, is in-between. But importantly, Merleau-Ponty stresses that such becomings are lived. Even if the reversibility of the flesh is "never realized in fact," the experience of its connecting-differenciating immanence is concrete and lived by our bodies (Visible 147).

In order to understand becoming-animal not only as theoretical proposition, but also as critical description with ontological, political and ethical import, I argue that we need to understand how we experience these molecular becomings as a mode of our lived embodiment. Moreover, this development of the notion of lived molecularity is crucial if we want to understand how it is that human bodies can nonetheless describe in a (rhizomatic) phenomenological manner the molecular dimensions of the real to which Deleuze and Guattari attend. As bodies that are not only sedimented subjects but also molecular compositions with affective, motor, perceptual and visceral capacities, we have a potentially shared molecularity 
with the things we seek to describe. Without the potential to tap into this lived molecularity (in spite of our tendencies towards subjectification), both Deleuze and Guattari's philosophy of becomings and Merleau-Ponty's ontology of the flesh would remain speculative and unconvincing. Furthermore, despite Deleuze and Guattari's distancing of themselves from the phenomenological project, a phenomenological rhizomatics is possible (perhaps ironically) for the same reasons that becoming-animal is possible. In their acknowledgement of our bodily molecularity, both show up the stable and discrete identity of the human as a sham. Our shared, lived molecularity, elicited by what Merleau-Ponty calls the reversibility of the flesh, is what facilitates the comingling or comixing that Deleuze and Guattari describe. "To emit a molecular dog" means to access some mode of our molecular embodiment - a growling hunger within our viscerality, a dejected whimper in our affectivity, even if such growls or whimpers are never actually emitted. Such molecularity extends beyond or below our cognitive, rational, subjectified modes of living and connects to the molecularity of the barking dog. This is no alchemy, for the becoming happens in between. There is no ultimate coincidence of man and dog; difference is retained in the becoming. Yet at the same time the becoming is also a transformation of the human (and the dog); the acknowledgement of this molecular connection activates a force countervalent to our subjectifying, stratifying selves.

\section{Describing Becoming-Animal: Affective and Motor Animal Symbioses}

My suggestion that Deleuze and Guattari's becoming-animal is a radical phenomenological proposition, in the sense that it describes a becoming-molecular of our lived experience, may not sit comfortably with readings of Deleuzian rhizomatics as explicitly counter- or even anti-phenomenological. This proposal, however, does not entail an erasure of 
the differences between rhizomatics and phenomenology, but rather seeks to articulate how the molecular flows of differenciation and interconnection of and between bodies described by Deleuze and Guttari can (and should) be understood as a mode of lived experience that can be described. The evocative descriptions of our lived bodily molecularity by phenomenologist Alphonso Lingis may help us appreciate this proposition.

In his book Dangerous Emotions, Lingis discusses two specific modes of human embodiment in terms of human-animal symbioses. The first of these is our affective bodies. Animal emotions, Lingis suggests, make our feelings intelligible; seeing our emotions in animals affirms their reality (35). He describes, for example, how "it is when we see ... the mother elephant carrying her calf in grief for three days, that we believe in the reality of maternal love." "It is the bull in the corrida that convinces us of the natural reality of fearlessness" (36). Secondly, Lingis also suggests that our motor bodies engage in a similar symbiosis with animals: it is animal movements whose rhythms and speeds we ebb and flow with, and which initiate our own movements. We "become animal" as "our legs plod with elephantine torpor," or "as our hands swing with penguin vivacity, our fingers drum with nuthatch insistence" (29). He notes that while human subjects live under the illusion of goal-oriented movement, most of our movements are not purposive at all, but rather are called out of us by the simple urge to move. Both our emotions and our movements are a response to the animal, vegetable, meteorological emotions and movements of which we are a part.

While Lingis does not explicitly connect our affective or our motor becomings with the bodily molecularity for which I argue above, this is surely what Lingis appreciates as he links these two modes of embodiment not only to our microscopic bacterial, microbial and cellular life, but also to the seasons, the weather, the skies and the oceans which ebb and flow within us. 
As Lingis writes, we find animal affectivity and movement so mesmerizing because what is fascinated in us are our inherent "multiplicities." For Lingis, these multiplicities are expressed equally in the "the pulses of solar energy momentarily held and refracted in our crystalline cells" and "the microorganic movements and intensities in the currents of our inner coral reefs" (28). Our molecularity—not as metaphor, not as scientific reduction, not as speculation, but rather as a modality of our lived embodiment—is the underlying enabler of these symbiotic motions and emotions. This experience, Lingis notes, is a surge or response of those multiplicities and intensities that are us, that are our bodies. Lingis's phenomenology of the myriad ways in which we "become animal" stresses that these becomings are the amplification of an event whose potential we already hold, as part of our molecular embodiment. Animals call something out of us, something often hidden by the cognitive, rational, concrete, inorganic overload of our Western existence. As Lingis explains, in the experience of sex, for example, we can feel "feline" or "foxy," and our bodies "transubstaniate into ooze, slime, mammalian sweat" (38). In such movements and emotions, "the ego loses its focus as center of evaluations, decisions, and initiatives. Our impulses, our passions, are returned to animal irresponsibility" (38). Here we also glimpse how, like Deleuze and Guattari, Lingis empahsizes the critical consequences such amplifications might have for our philosophical paradigms governing subjectivity, embodiment and ontology more generally. Lingis's phenomenology affirms that the idea of a subject-self, discretely bound by the form of its body, is only a temporary fiction. Just because "we" take the form of "bodies," claims Lingis, we should not assume that this form is what gives us singularity or individuation. Just as a fog or a swarm, he notes, retains individuality without being a subject, we humans also retain this singularity in our molecular compositions and interactions. ${ }^{7}$ As molecular multitudes we certainly pause within subjectivity as a convenient place from which to 
undertake human subjectified endeavors, but we should be wary of using this ephemeral cognitive composition as an ontological justification for superiority or privilege. Hence just as Deleuze and Guattari's descriptions carry with them both implicit and explicit calls to action ("Make rhizomes!" "Experiment!"), so does Lingis implore us to learn something from our animal symbioses: "Let us see through the simple-mindedness that conceives of the activities of [the body's] parts as functionally integrated and conceives it as a discrete unit of life" (28).

Lingis's phenomenological descriptions share other specific affinities with Deleuze and Guattari's becoming-animal concept. Lingis too stresses that these affirmations of our "animal selves" are never an imitation, or a voluntaristic act to become "like" the animal. If becoming animal is ever "triggered" by the actual presence of the animal (as both Deleuze and Guattari, and Lingis, would agree), this is not because we want to imitate, but because this animal is an evocation, a beckoning, or even an agent of combustion with our own molecularity. It is this swarming, this intensity from which our bodies are made, that is called forth in such encounters. In Merleau-Ponty's terms, these are the others that are latent within us. Moreover, Lingis's descriptions of our embryonic "animal potentiality" do not posit a relationship of filiality or "progression" between animal and human. Just as the "animal" is already in us, so is the mushroom, the sea sponge, glacial ice, autumn wind, meteoric dust in space. Becoming-animal is not a relationship determined by evolutionary progression, but one determined by the shared matter, energy and forces of which all of these bodies partake in their in-betweens. Again, the concurrence with Deleuze and Guattari here is clear. For Lingis, as for Deleuze and Guattari, these becomings are an amplification of the in-between of animal and human that is part of our embodiment's network of becoming and connection to its presumed others. 
Interestingly, Lingis explicitly cites neither Deleuze and Guattari's becoming-animal, nor Merleau-Ponty's philosophy of lived embodiment, in relation to any of the descriptions from this chapter of Dangerous Emotions discussed above. He is, nonetheless, clearly familiar with both of these corpuses of work. ${ }^{8}$ In fact, despite this particular lack of reference to Deleuze and Guattari's becoming-animal, Lingis is not only evidently indebted to its concepts but even borrows its images and examples_-for instance, his reference to our human bodies as having the individuality of a pack, a swarm, a fog, a season. Yet the reason for our excursion into Lingis's work here is not to enumerate the ways in which Lingis takes up Deleuze and Guattari's theory; the objective is rather to provide an illustration of how Deleuze and Guattari's description can be further fleshed out in deep and evocative complementary phenomenological descriptions of lived human embodiment. Lingis's descriptions help us understand how our bodily molecularity is neither abstract scientific truism nor metaphoric extrapolation, but rather something we live, and in this case, something that connects us deeply and intimately to animals with whom we share this molecularity. Lingis's phenomenology of our animal motions and emotions stresses that these unnatural becomings are not mysteriously created by chance encounters with the animal, but rather actualize an energetic potential already stirring within us, that is an integral aspect of our lived embodiment. Our potential to "become animal" exists because our bodies can only ever do, or know or feel anything at all as bodies in the world, as bodies whose capacities and structures are called forth by what is in the world. In this sense, Lingis's work provides a helpful bridge for connecting the molecularity that Deleuze and Guattari describe as a key to becoming animal, and the lived human embodiment that Merleau-Ponty theorizes through his descriptions of the body's various interconnected modalities and its chiasmic relation to the flesh of the world. 
In these ways, Lingis's descriptions deepen our understanding of becoming-animal as an event of our bodily molecularity. Like Deleuze and Guattari, Lingis also uses becoming-animal to gesture towards a critical loosening of our stratified human subjectivities. Yet while Lingis's descriptions evoke the beauty and awe of becoming-animal as a lived experience, Deleuze and Guattari also remind us that becoming-animal can be botched. It is neither simple nor fool-proof. They caution us that like all experimentation, becoming-animal is risky. Despite the important phenomenological insights that arise from Lingis's descriptions, they do not impart to us what these risks of becoming-animal might be. Nor do they address the fact that, as Deleuze and Guattari tell us, all becomings are double. What are the risks, and do they apply only to the human? How might these risks be relevant to the animal? If humans stand to gain a desedimentation of subjectivity through becomings-animal, what do animals stand to gain? Or lose?

\section{Becoming Grizzly}

These questions bring us to Werner Herzog's acclaimed 2005 documentary film, Grizzly Man. Timothy Treadwell spent thirteen summers in Alaska, living with grizzly bears. He claimed that the only way to protect this species (primarily from poachers) was to live with them in their natural habitat, gain their trust, and serve as their sentinel. Significantly, when Treadwell embarked on this mission he was neither biologist nor environmentalist, and knew next to nothing about bears or wilderness survival. Rather he was an out-of-work actor battling various demons and addictions who claimed to have found life's meaning in Alaska. This was where, in 2003, Treadwell and his girlfriend were attacked by a grizzly bear and killed. Treadwell made videos of much of his time in Alaska and used them to promote respect and protection for the 
grizzlies. He spent his winters showing his films and giving lectures, and was the co-founder of Grizzly People, a society whose main aim is the protection of the grizzly population and habitat. But his film footage was not only about the grizzlies; it was also about Treadwell himself. Watching it, one is conscious of the alternating role Treadwell's camera occupies as diary of a lonely bush-feverish soul, and audience to a failed actor desperate for a public. This is the story that documentary filmmaker Werner Herzog saw in the footage, and which he turned into the film Grizzly Man. As Herzog says at the end of the film, Treadwell's footage "is not so much a look at wild nature as it is an insight into ourselves." This insight, I argue, includes an exploration of becoming-animal and its consequences and risks not only for the human, but for the animal as well. .

Herzog interviews various people in his film who describe Treadwell's relations in ways that both support and challenge the notion of his becoming-animal. A biologist, a pilot, and an Alutiiq anthropologist (none of whom had actually met Treadwell) are extremely critical of Treadwell's attempts to "be like the bears." They all suggest that Treadwell sought to cross the line that ultimately separates the human from the bear, with catastrophic consequences. According to such views, Treadwell did not so much "become-animal" as he engaged in a voluntaristic representation or imitation that was doomed to failure and tragedy. Alternately, a Deleuzian sense of becoming-animal rings clearly in others's descriptions of Treadwell. Ecologist Marnie Gaede concurs that Treadwell "wanted to become like the bear," yet she is careful to explain that this was not an imitation but an act of deep and quasi-religious connection. She describes this as "the sense of connecting so deeply that you're no longer human." Herzog himself sees Treadwell as clearly grappling with a human subjectivity by which he felt stifled: "Treadwell reached out seeking a primordial encounter... as if there was a desire in him to leave 
the confines of his humanness and bond with bears." "Wild primordial nature is where he felt truly at home."

Yet even if we are drawn in by Gaede and Herzog's theories about Treadwell, his own footage and diary entries provide the most evocative material for analysis. Here is where we can glimpse the becoming-animal that was not a voluntaristic project of Treadwell's, but a molecular exchange between him and the animals he lived with. We see, for example, the animal movements that well up in Treadwell in the presence of the grizzlies. He lumbers, keeping his head low and his eyes unchallenging (most often hidden by black-lensed sunglasses). He intuits his rank alongside the submissive grizzlies, deferring authority to the more dominant and aggressive bears in the group. At the same time we can observe his sense that these movements also have to express (or at least feign) confidence and assurance, as Treadwell knows that evident fear and total submission will result in attack. Among the bears, his posture and his gait accustom themselves to the grassy plain, the maze of trees and the sandy flats that comprise the home of the bears. His affective molecularity is also called out in response to the animal emotions in which he becomes entangled-we see this for example in his heart-felt affinity with the dogged determination of Mickey the bear, who loses a tussle with Sergeant Brown. But these molecular encounters with the grizzlies do not comprise Treadwell's only animal symbioses. While he "emits a molecular Grizzly" in the presence of the bears, footage of Treadwell's downtime on his expeditions reveals his clear motor and affective connections to the foxes of the Alaskan peninsula. Treadwell's mischievous antics and sprinting movements, stubborn and vaguely childish pouts, and playful yet also stroppy mannerisms reveal a becoming-fox that is perhaps even stronger than his becoming-bear. In one scene, as he speaks splenetically of the torture and sport killing to which foxes are subject, the visual resemblance between Treadwell 
and the fox by his side is uncanny. This is surely no studied imitation of one by the other, yet the molecular connection between the two is palpable in their mannerisms, posture, gaze and appearance.

What both Treadwell's becoming-grizzly and becoming-fox have in common are the growing disdain and annoyance with the human world that these becomings elicit in Treadwell. Both animal becomings pull Treadwell increasingly further from his subjectified human identification and towards the interconnectivity of the imperceptible. As Treadwell describes to the camera his camp in the Grizzly Maze, he notes his need to "remain hidden from the authorities, from the people that would harm me, from people who would seek me out as a story. My future helping the animals depends on it. I must be a spirit in the wilderness." We have the sense of Treadwell wanting to dissipate, if he could, into the air, the trees, the waters of the Alaskan coast. After Treadwell's death, as his friends return to Katmai to scatter his ashes, one friend remarks: "He finally figured out a way to live here forever."

Deleuze and Guattari note that the movement towards the imperceptible is determined by the various thresholds or doors that one encounters-thresholds we clearly mark in Treadwell's own transformation. This is evidenced perhaps best in the "I touched her poop" scene, where Treadwell ecstatically fingers the excrement fresh out of Wendy the bear. "It's Wendy's poop!" he exclaims to the camera. "I touched her poop! I know it may seem weird that I touched her poop, but it was inside her. It's what...-it's her life. It's her." Some read this scene as proof of Treadwell's mental instability, of his definitive loss of touch with reality. Perhaps. But if so, then this loss is also part of his becoming-animal moving towards a becoming-imperceptible_part of his (molecular, non-cognitive) realization of the interconnectedness of life through matter, and his progressive loss of commitment to a discrete and compartmentalized humanity. In Deleuze 
and Guattari's terms, the "poop" is one of the doors, the thresholds through which Treadwell can leave the fiction of self and acknowledge a zone of material multiplicity.

But, as Deleuze and Guattari remind us, the movement of becoming-animal is always caught up in other forces and other movements, including the pressure of the plane of organization to continually recapture, resediment and restratify. In Treadwell's case, we see how his becoming-animal struggles against his rock-star fantasy to be famous, to be recognized as "Grizzly Man.” Treadwell's "look at me" moments, as he struts, bellows and rages at the camera, reveal the tension he feels between these two opposing pulls—one toward becoming recognized, the other toward becoming imperceptible; one toward the plane of organization, the other toward the plane of consistency. Moreover, as Herzog observes, Treadwell's "larger, more placable enemy" was the "people's world and civilization itself: he only has mockery and contempt for it." Treadwell surely resents this world not only for the threat it poses to the grizzlies, as Treadwell the naturalist would have us believe, but also for the threat it poses to the becominganimal and becoming-imperceptible that Treadwell feels carrying him away. Being with the bears, states Treadwell, “is the only thing I know. It's the only thing I want to know." His experiences with these animals, he tells us, gave him a life.

Yet we also know that complete or pure becoming results in annihilation, for one needs to retain "a minimum of strata, a minimum of forms and functions, a minimal subject from which to extract materials, affects and assemblages" in order to hold the becoming in the middle (Deleuze and Guattari, Thousand 270). Otherwise becoming collapses in on itself, with no assemblages on either side to fuel it. Deleuze and Guattari warn us of such risks of becoming-animal, and the possibility that it may be "botched." Was Treadwell's death (and the death of Amie Huguenard in the tent beside him) the annihilation of which Deleuze and Guattari warn us- the becoming- 
animal collapsing in on itself? And if the pull of this becoming was too strong, and the becoming did implode, was this the failure of the becoming? Or was it the failure of the other strata, of other bodies and worlds that populated either side of this becoming — to accommodate and allow it? In Herzog's film, Larry van Deale, a biologist who had never met Treadwell, talks on camera about Treadwell's life and death:

When you spend a lot of time with bears, especially when you're in the field with them day after day, there's a siren song, there's a calling that makes you want to come in and spend more time in their world because it is a simpler world, it is a wonderful thing, but in fact it's a harsh world, it's a different world that bears live in than we do, so there's that desire to get into their world, but the reality is that we never can.

Yet Treadwell did get into their world, at least temporarily. At least molecularly. While the world of the wild animal certainly has its own plane of organization quite different from that of human subjectivity, no person who has ever spent intimate time in the company of a wild animal will deny the connective potential one senses bubbling beneath the chasm of our difference: a sidelong glance, a frightened whimper, an aggressive lunge-those emotions and movements that Lingis describes as making our own emotions and movements meaningful. As Treadwell tells his friends, "if I don't make it back, then that's the way I wanted it to be." He tells his friends that he suspects his life and his work would be more meaningful in his death. Treadwell's death is certainly the annihilation of his worldly body-assemblage, but must it also be the annihilation of the lesson to be learned from his becoming? His increasing commitment to the becoming suggests that this death may have been a failure only from the perspective of the human subject. From the perspective of the becoming, such a death may have been a consistent outcome—in some ways, another door or threshold. Herzog's film, and perhaps in a smaller way this paper, suggest that Treadwell's suspicions about the impact of his own death were correct. Treadwell's life and death afford us a touchstone from which to challenge our inherited 
definitions of what it means to be embodied, and specifically human-bodied. We are invited to draw new parameters for an ontology of life based on the interpermeations of bodies of all kinds and the traversal of our lived molecularity in and through these bodies. His becoming asks us to consider both what facilitates and what holds us back from experiencing the ways in which our bodies plug into other registers, other strata, other bodies.

Yet Treadwell's example also offers us an opportunity to consider the very real material risks and effects involved in a Deleuzian experiment such as becoming-animal. The first aspect of these risks has already been addressed. Despite what we can learn from his becomings, the fact remains that Treadwell and his girlfriend suffered a horrible death at the hands of a grizzly bear. It is worth noting that the bear that killed Treadwell and Huguenard was not one that Treadwell had "befriended," but likely a bear from the interior, that had come to look for food at the end of the season, after Treadwell's grizzly companions had already settled in for their long winter nap. Treadwell had in fact already left for the year, but on an impulse returned to the Grizzly maze for one last visit before going back south. This was, after all, a milieu that he had built together with the bears, one where he had found he was able to live. But what was this stranger bear to know of Treadwell's becoming-animal, of the mixing of molecules at work between him and Wendy, Mr. Chocolate, Sergeant Brown, Mickey, Downey and the others? It was late in the season. Very few salmon carcasses still littered the bottom of the lake. We all know how visceral hunger can easily dominate any affective or motor impulses that may surface in other circumstances. A successful becoming-animal is only ever a potential, never a guarantee. It can be thwarted for all sorts of reasons. In his world, this bear was simply hungry.

Or perhaps, this bear was drawn into a becoming-animal with Treadwell because of this very viscerality that consumed him in his autumn hunger. Perhaps this final becoming is an 
example of Deleuze and Guattari's insistence that some becomings-animal are necessarily violent, unnatural, unanticipated. Molecules unexpectedly mix. Why not the visceral molecularity of a hungry bear, and the nutritive molecularity of a fleshy body?

This suggestion leads us to consider a second material risk of becoming-animal. We know that becoming-animal is always a mutual becoming, a double movement "affecting the animal no less than the human" (Thousand 237). Because such becomings are neither symmetrical nor reciprocal, Deleuze and Guattari cannot posit exactly what the animal will become, except to say that it too will "become other" (238). They note, moreover, that "the politics of becomings-animal remains, of course, extremely ambiguous" (247). Yet, their comments on the risks here are focused solely on the human who becomes - the sorceress who is burned, the man-dog who is domesticated, the woman-bird who is turned into a totemic correspondence. But what of the animals? This key characteristic of becoming-animal is not discussed by Deleuze and Guattari in detail in any of their examples, and is similarly left out of Lingis's descriptions of our motor and affective animal symbioses. But Grizzly Man forces us to pursue the question: What is this "other" that the animals become, and what are the risks and consequences of their becoming? What does their becoming teach us?

What if, in our particular case, the "other" that the grizzlies become is the antithesis of the increasingly-imperceptible? What if the grizzlies, through Treadwell's becomings, become hyper-perceptible and very subjectified? What if they become human-bears, susceptible to our laws and our codes? After all, for a grizzly to kill a grizzly is just "nature's way." But for a grizzly dragged into a becoming he probably would rather have avoided, to kill a human is "murder." In our world, such crimes are punishable by death. I wonder: If becoming-animal demands a comixing of energies, an exchange of forces, by way of a viral contagion-might not 
the grizzlies take on some of what it means to be an ontological being in a human-centred world? And what are the implications of this?

Wildlife scientists remark that habituating grizzlies to the presence of humans endangers their lives. Bears learn that humans are not to be feared or avoided, when indeed they should be-for the safety of both bear and human. Even Treadwell's Grizzly People website notes that "people should remain 100 yards from bears at all times," in concurrence with the National Park rules that Treadwell violently rails against in his footage. In the film, Sven Haakanson, an Alutiiq anthropologist, comments that this tragedy ensued because Treadwell crossed the line between human and bears - a line, Haakanson remarks, that his people have lived with and respected for 7000 years. Yet in some ways, the becoming-human of the animal can certainly benefit the grizzlies. As Treadwell's Grizzly People website notes, despite the warnings of wildlife scientists, Treadwell's presence in the Katmai reserve meant that no grizzly deaths by poaching occurred during the summers he sojourned there, even though before and after, these killings persevered. And while the anthropomorphization of non-humans can enact a sort of ontological violence, understanding an animal in human terms has nonetheless been proven to be a strong deterrent to senseless killing, for sport or otherwise.

Nonetheless, in the case of Grizzly Man it was not only Timothy Treadwell and his girlfriend Amie Huguenard who lost their human lives, but also the bear, who was thereafter hunted down and shot—not only an "obvious danger" to the human population, but also a "murderer." The becoming is double, and so is the tragedy. Treadwell claimed he would never kill a bear in defence of his own life. He claimed that if he were to die on the peninsula, then that would be the appropriate outcome. Yet the becoming he pursued had implications far beyond his 
own ephemeral body-assemblage. The molecularity of the becoming continued-and continues—-to knock on other doors, to cross other thresholds.

We cannot charge Deleuze and Guattari with "reckless philosophizing." They warn us of the risks of becoming-animal as clearly as though there were a skull-and-crossbones on the jacket of their book. And Grizzly Man nonetheless serves as an important touchstone for considering our beautiful interpermeations with other bodies-animal, vegetable, geological, cosmological—not only in their ontological import, but in their ethical import too. With these other bodies we share matter, and force, and energy - an interconnecting molecularity. But the same movements of this matter, force and energy also safeguard our difference; we do not "really" become animal. So in our becomings-animal I wonder if we have a responsibility, too.

And I wonder if we know what to do with it.

\section{Notes}

${ }^{1}$ Deleuze and Guattari's statements on filiation, evolution and becomings can be misleading here. They write: "Becoming is not an evolution, at least not an evolution by descent and filiation. [...] If evolution includes any veritable becomings, it is in the domain of symbioses that bring into play beings of totally different scales and kingdoms, with no possible filiation" (Thousand 238). This passage should not be misconstrued to mean that the two terms involved in becoming-animal must be "of totally different scales and kingdoms" or that there are no commonalities of connection between the terms. To assume this would be to disregard Deleuze and Guattari's entire philosophy of neo-materialist rhizomatic interconnectivity. What this passage does highlight is that evolutionary filiation, which establishes chronological ordering and hierarchy between discrete species, should never be mistaken for a becoming-animal. "Scales and kingdoms" should be understood as belonging to the plane of organization that is at the same time being interrupted by the plane of consistency and destratifying forces. The lesson here is not that evolution has no becomings, but rather that our common understandings of evolution must be rethought to better accommodate the mechanics of symbioses and creative becomings.

2 Hardt and Negri's recent work (2004) relies on this prescriptive element in Deleuze and Guattari that enjoins us to become multitudes. Feminist theorists such as Rosi Braidotti (2002, 
2006) and Elizabeth Grosz (2005) deploy Deleuze and Guattari's work in aid of an antiessentialist or "nomadic" feminist politics of becomings.

3 For deeper descriptions of the actual and virtual see Deleuze, "The Actual and the Virtual" (2002) and Difference and Repetition (1994: e.g. 208-214).

${ }^{4}$ See DeLanda (2002) for a comprehensive description of the ways in which the intensive is figured as a necessary aspect of a Deleuzian ontology.

I I owe this particular categorization of bodily modalities to S. Mallin's work on Merleau-Ponty. See his book Merleau-Ponty's Philosophy (1979). It should be noted that neither Merleau-Ponty nor Mallin explicitly acknowledge viscerality as an irreducible bodily modality. However, following Drew Leder's convincing argument in The Absent Body (1990), it seems that viscerality should certainly be included in this list. It is in no way incompatible with the general tendencies of Merleau-Ponty's description of embodiment.

It is also important to note that the particular understanding of "cognition" and the "cognitive body" I use here may be misconstrued in the context of our contemporary theoretical landscape. Cognition here does not refer to the neurological body that is the subject of emerging studies in continental philosophy and cognitive science. This emerging understanding of a neurological bodily modality would be more closely aligned with the visceral body in my listthat body made up of the physiological processes that often seem to operate below our subjectified perceptual threshold.

${ }^{6}$ Other commentators who suggest that Merleau-Ponty's ontology indeed represents a significant departure from the humanist subjective standpoint include Weiss (1999), Barbaras (2004) and Kirby (2006). Kirby refers to Merleau-Ponty's work as a radical assault on our routine notions of subjectivity, particularly in its location of a differential that is both within the subject and connected outwards towards the bodies of others. Weiss notes the way that the notion of écart developed by Merleau-Ponty as that which can both connect bodies and safeguard difference has an important place in Deleuze's philosophy in terms of movements of desire and multiplicity (119-128). Barbaras reads in Merleau-Ponty an important prefiguring of a Deleuzian nondialectical ontology. These are the suggestions that I am picking up on and playing out in more detail in my suggestion of the rhizo-phenomenon of bodily molecularity as both connector and differenciator.

${ }^{7}$ This passage in Lingis not only shares a common ontological conclusion with Deleuze and Guattari, but is in fact a direct reference to A Thousand Plateaus where they write: "You are a longitude and latitude, a set of speeds and slownesses between unformed particles, a set of nonsubjectified affects. You have the individuality of a day, a season, a year, a life (regardless of its duration) — a climate, a wind, a fog, a swarm, a pack (regardless of its regularity)" (262).

${ }^{8}$ Lingis is the English language translator of Merleau-Ponty's The Visible and the Invisible, and makes many references to Deleuze and Guattari's work both elsewhere in Dangerous Emotions, and in other books as well. 


\section{Works Cited}

Barbaras, R. The Being of the Phenomenon: Merleau-Ponty's Ontology. Trans. T. Toadvine and L. Lawlor. Bloomington: Indiana University Press, 2004.

Braidotti, R. Metamorphoses. Cambridge: Polity, 2002.

—. Transpositions. Cambridge: Polity, 2006.

DeLanda, M. Intensive Science and Virtual Philosophy. New York: Continuum, 2002.

Deleuze, G. "The Actual and the Virtual." Trans. E. R. Albert. Dialogues II. New York: Columbia University Press, 2002. 148-152.

—. Difference and Repetition. Trans. P. Patton. New York: Columbia UniversityPress, 1994.

Deleuze, G. and Guattari, F. A Thousand Plateaus. Trans. B. Massumi. Minneapolis: University of Minnesota Press, 1987.

—. What is Philosophy? Trans. H. Tomlinson and G. Burchell. New York: Columbia University Press, 1994.

Grizzly People. www.grizzlypeople.com

Grosz, E. Time Travels. Durham: Duke, 2005.

Hardt, M. and A. Negri. Multitude. New York: Penguin Press, 2004.

Herzog, W. Grizzly Man. Lion's Gate. 2005.

Kirby, V. "Culpability and the Double Cross: Irigaray with Merleau-Ponty." Feminist Interpretations of Merleau-Ponty. Eds. D. Olkowski and G. Weiss. Pennsylvania State University Press: University Park, 2006.127-146.

Leder, D. The Absent Body. Chicago: University of Chicago Press, 1990.

Lingis, A. Dangerous Emotions. Berkeley: University of California Press, 2000.

Mallin, S. Merleau-Ponty’s Philosophy. New Haven: Yale University Press, 1979.

Merleau-Ponty, M. “The Experience of Others.” Trans. F. Evans and H. J. Silverman. Review of Existential Psychology and Psychiatry 28 (1982-83). 1-3. 
-. Phenomenology of Perception. Trans. Colin Smith, New York: Routledge, 1962.

-. The Visible and the Invisible. Trans. Alphonso Lingis. Evanston: Northwestern University Press, 1968.

Weiss, G. Body Images: Embodiment as Intercorporeity. New York: Routledge, 1999. 